\title{
ANALISIS FAKTOR PENERIMAAN DAN PENGGUNAAN SOFTWARE ACCURATE DALAM PERSPEKTIF TECHNOLOGY ACCEPTANCE MODEL \\ (Studi Empiris pada Mahasiswa Program Studi S1 Jurusan Akuntansi Fakultas Ekonomi Universitas Tadulako)
}

Rendy Rekka ${ }^{1}$, Chalarce Totanan ${ }^{2}$, Sudirman ${ }^{3}$, Arung Gihna Mayapada ${ }^{4}$

${ }^{1}$ Mahasiswa Jurusan Akuntansi Fakultas Ekonomi Universitas Tadulako Palu 2,3,4 Dosen Jurusan Akuntansi Fakultas Ekonomi Universitas Tadulako Palu

\begin{abstract}
This study aims to analyze acceptance and usage factors of Accurate Software based on the perspective of technology acceptance model. These factors include perceived ease of use, perceived usefulness, and behavioral intention to use. We also add some external variables which are pressure to use and computer self efficacy. The data of this study are obtained from questionnaires and measured using Likert scale. The analysis method used in this study is partial least square (PLS). The sample is bachelor degree students of 2014, 2015, and 2016 batches in Accounting Department in Faculty of Economics in Tadulako University. The results of the study show that perceived ease to use, perceived usefulness, behavioral intention to use, pressure to use, and computer self efficacy have significant effect to actual usage of Accurate Software. The results of this study verify technology acceptance model.
\end{abstract}

Key Words: Technology Acceptance Model, Perceived Ease of Use, Perceived Usefulness, Behavioral Intention to Use, Pressure to Use, Computer Self Efficacy, Actual System Usage

\begin{abstract}
ABSTRAK
Penelitian ini bertujuan untuk menganalisis faktor-faktor penerimaan dan penggunaan software Accurate berdasarkan sudut pandang technology acceptance model. Faktor-faktor tersebut adalah persepsi kemudahan penggunaan, persepsi kegunaan, dan perilaku keinginan untuk menggunakan. Kami juga menambahkan variabel eksternal lainnya yaitu tekanan untuk menggunakan dan kemampuan menggunakan komputer. Data penelitian ini diperoleh dari kuesinoer dan diukur menggunakan skala Likert. Metode analisis yang digunakan pada penelitian ini adalah partial least square (PLS). Sampel penelitian ini adalah mahasiswa program studi S1 angkatan 2014, 2015, dan 2016 pada Jurusan Akuntansi Fakultas Ekonomi Universitas Tadulako. Hasil penelitian ini menunjukkan bahwa kemudahan penggunaan, persepsi kegunaan, perilaku keinginan untuk menggunakan, tekanan untuk menggunakan, dan kemampuan menggunakan komputer berpengaruh signfikan terhadap penggunaan software Accurate sesungguhnya. Hasil tersebut memverifikasi technology acceptance model.
\end{abstract}

Kata Kunci: Technology Acceptance Model, Kemudahan Penggunaan, Persepsi Kegunaan, Perilaku Keinginan untuk Menggunakan, Tekanan untuk Menggunakan, Kemampuan Menggunakan Komputer, Penggunaan Aktual Sistem

\author{
Jurnal Akun Nabelo: \\ Jurnal Akuntansi Netral, Akuntabel, Objektif \\ Volume 1/Nomor 2/Jan 2019 \\ Jurusan Akuntansi FE-Universitas Tadulako
}

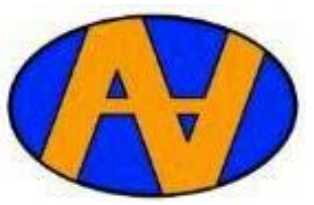




\section{A. PEndahuluan}

Perkembangan teknologi di era ini terus terjadi dan mengalami peningkatan yang cukup pesat. Perkembangan tersebut meliputi dua bagian penting yaitu hardware (perangkat keras) dan software (perangkat lunak). Berdasarkan perkembangannya tersebut, terdapat perbaikan secara umum. Software merupakan perangkat lunak dan paling sering digunakan oleh users. Oleh sebab itu, perangkat lunak pula yang paling sering dikembangkan, sehingga pengguna bisa nyaman menggunakannya.

Jogiyanto (2005) menyatakan bahwa meskipun kualitas teknologi informasi sudah mengalami peningkatan saat ini, tetapi masih juga ditemukan beberapa teknologi informasi yang gagal dalam pengaplikasiannya. Hasil penelitian terdahulu mengungkap bahwa penyebab kegagalan pengaplikasian teknologi baru terletak pada perilaku users.

Teori technology acceptance model (TAM) dikembangkan dari teori reasoned action oleh Ajzan \& Fishbein (1980) dengan menambahkan dua konstruk utama yaitu persepsi kegunaan (perceived usefulness) dan persepsi kemudahan dalam menggunakan (percieved ease of use). Oleh sebab itu, konstruk utama TAM meliputi lima bagian utama, yaitu persepsi kegunaan (perceived usefulness), persepsi kemudahan dalam menggunakan (perceived ease of use), sikap dalam menggunakan teknologi (attitude towards using technology), perilaku minat untuk menggunakan teknologi (behavioral intention to use), dan penggunaan teknologi secara aktual (actual technology use). Lima konstruk tersebut selanjutnya digunakan untuk meneliti bagaimana penerimaan suatu teknologi bagi users.

Komputer akuntansi merupakan mata kuliah yang wajib untuk di program oleh mahasiswa jurusan akuntansi yang mana dalam mata kuliah tersebut software yang digunakan adalah Accurate. Accurate merupakan software yang digunakan untuk mempermudah pengelolaan data keuangan dengan tingkat akurasi yang tinggi sehingga menghasilkan laporan keuangan dengan lebih cepat dan tepat. Oleh karena itu, penelitian terhadap software Accurate ini berdasarkan sudut pandang TAM kepada mahasiswa yang telah memprogramkan mata kuliah tersebut perlu untuk dilakukan dalam rangka untuk mengetahui bagaimana penerimaan dan penggunaan dari software Accurate ini di kalangan mahasiswa Program Studi S1 Jurusan Akuntansi Fakultas Ekonomi Universitas Tadulako. Berdasarkan dari pemaparan di atas, kami akan meneliti tentang faktor-faktor penerimaan dan penggunaan software Accurate berdasarkan sudut pandang TAM pada mahasiswa Program Studi S1 Jurusan Akuntansi Fakultas Ekonomi Universitas Tadulako.

\section{B. TELAAH PUSTAKA}

Teori reasoned action atau tindakan beralasan dikembangkan oleh Icek Ajzen dan Martin Fishbein pada tahun 1980. Teori reasoned action menjelaskan bahwa sebuah perilaku timbul karena individu memiliki niat atau keinginan untuk melakukan perilaku tersebut (behavioral intention). Niat akan menentukan perilaku.

Teori planned behavior atau perilaku terencana merupakan pengembangan lebih lanjut dari teori reasoned action yang dikembangkan oleh Icek Ajzen pada tahun 1988. Teori planned behavior menambahkan konstruk persepsi pengendalian perilaku (perceived behavioral control). Perilaku dibatasi oleh kekurangan sumber daya dalam rangka melakukan perilaku tersebut.

Technology acceptance model (TAM) adalah model yang dikembangkan oleh Davis pada tahun 1986. TAM merupakan 
sebuah model yang menggambarkan penerimaan sebuah teknologi informasi oleh users. Model TAM merupakan pengembangan lebih lanjut dari teori reasoned action. TAM sering kali digunakan pada penelitian sistem informasi sebab model ini mudah untuk diterapkan dibandingkan model-model lainnya. Selain itu, TAM telah banyak diuji dan diverifikasi oleh penelitianpenelitian terdahulu. Sehingga, TAM diyakini sebagai model yang baik.

Beberapa peneliti melakukan pengembangan terhadap TAM dengan menambahkan beberapa faktor eksternal yang menerangkan lebih lanjut atau menjadi penyebab (accedent) dari persepsi kegunaan (perceived usefulness) dan persepsi kemudahan dalam penggunaan (perceived ease of use) pada TAM. Pada umumnya, gambar berikut adalah gambaran umum model TAM yang dimodifikasi dengan tambahan variabel eksternal.

Berdasarkan beberapa penelitian sebelumnya mengenai TAM dan juga dalam buku Jogiyanto (2007) dinyatakan bahwa dua konstruk TAM bisa dihilangkan, yaitu sikap terhadap perilaku (attitude towards behavior) dan perilaku (behavior). Sikap terhadap perilaku dapat dihilangkan sebab beberapa hasil penelitian-penelitian terdahulu menunjukan bahwa sikap (attitude) tidak memiliki pengaruh signifikan terhadap niat perilaku (Jogiyanto, 2007). Sementara itu, konstruk perilaku dapat dihilangkan karena TAM seharusnya mengukur penggunaan teknologi secara aktual (actual usage). Namun, mayoritas penelitian terdahulu mengukur penggunaan teknologi berdasarkan yang dilaporkan sendiri oleh responden (self-reported) dan berdasarkan perkiraan responden (self-predicted) yang mana keduanya diduga tidak menggambarkan pemakaian sesungguhnya (Jogiyanti, 2007).

Pada beberapa penelitian terdahulu seperti Venkatesh et al. (2003), Darsono (2005), Budiono dan Permana (2012), serta Akbar \& Ginting (2014) yang melakukan penelitian mengenai TAM. Mereka melakukan modifikasi terhadap bentuk asli TAM dengan menambahkan dan mengurangi beberapa konstruk dari TAM yang disesuaikan dengan kebutuhan peneliti. Abdel (2008) melakukan penelitian yang memodelkan minat siswa dalam mengadopsi e-learning. Pada model tersebut, variabel tekanan untuk menggunakan (pressure to use) ditambahkan ke dalam model dasar dari TAM. Hasil penelitian tersebut menunjukan bahwa variabel pressure to use memberikan pengaruh terhadap minat siswa dalam menggunakan $e^{-}$ learning. Pada penelitian tersebut, variabel pressure to use digunakan dengan pertimbangan bahwa penggunaan sistem ujian online oleh subjek penelitian ini dapat dipaksakan oleh pihak sekolah sebagai sistem evaluasi pembelajaran formal yang harus diikuti oleh seluruh siswa. Begitu halnya, jika dilakukan di kalangan mahasiswa yang menggunakan suatu software karena suatu kewajiban dalam perkuliahan yang secara tidak langsung memaksakan mahasiswa untuk mengambil mata kuliah tersebut. Dalam hal demikian, rumusan hipotesis pertama adalah:

H1: Tekanan untuk menggunakan (pressure to use) berpengaruh signifikan terhadap persepsi kegunaan (perceived usefulness).

Ketika seseorang memiliki ability atau kemampuan untuk menggunakan suatu komputer, maka ia akan percaya ketika menggunakan suatu sistem yang baru ia tidak akan mengalami kesulitan. Pada beberapa penelitian terakhir ditemukan bahwa terdapat hubungan positif antara kemampuan menggunakan komputer terhadap persepsi kemudahan (Ghina et al., 2015). Hasil dari penelitian tersebut mengungkap bahwa kemampuan menggunakan komputer berdampak positif dalam membentuk persepsi kemudahan. Hal ini berarti semakin baik kemampuan mahasiswa dalam menggunakan komputer maka 
semakin mudah bagi mahasiswa tersebut menggunakan sistem informasi lainnya. Oleh sebab itu, hipotesis yang kami rumuskan adalah.

H2: Kemampuan menggunakan komputer (computer self-efficacy) berpengaruh signifikan terhadap persepsi kemudahan dalam penggunaan (perceived ease of use).

Pada TAM, kedua konstruk tersebut merupakan konstruk utama yang membedakan TAM dengan teori reasoned action secara signifikan. Oleh sebab itu, kedua konstruk tersebut selalu didapatkan dalam penelitian mengenai TAM.

Hasil penelitian Chan (1996) menunjukkan persepsi kemudahaan dalam penggunaan berpengaruh signifikan terhadap persepsi kegunaan, minat untuk menggunakan, dan penggunaan aktual. Sementara itu, Suseno (2009) menemukan persepsi kemudahan dalam menggunakan berpengaruh positif signifikan terhadap persepsi kegunaan. Maka dari itu, hipotesis yang dirumuskan adalah:

H3: Persepsi kemudahan dalam menggunakan (perceived ease of use) berpengaruh signifikan terhadap persepsi kegunaan (perceived usefulness).

Davis (1989) mengungkap bahwa hubungan persepsi kegunaan terhadap penggunaan aktual lebih kuat dibandingkan dengan hubungan konstruk lainnya. Temuan tersebut sejalan dengan Szajna (1996) dan Akbar \& Ginting (2014). Selain itu, penelitian terdahulu mengungkap bahwa persepsi kegunaan juga berpengaruh terhadap perilaku minat untuk menggunakan (Iqbaria et al., 1994; Venkatesh \& Morris, 2000; Taylor \& Todd, 1995; Tang \& Chiang, 2009). Maka dari itu, hipotesis dirumuskan sebagai berikut:

H4: Persepsi kemudahan dalam penggunaan (perceived ease of use) berpengaruh signifikan terhadap perilaku minat untuk menggunakan (behavioral intention to use).

Akbar \& Ginting (2014) dalam penelitiannya mengenai perimaan penerapan sistem ujian online pada siswa SMKN 13 Bandung melakukan penelitian terhadap konstruk ini. Hasil dari penelitian tersebut adalah siswa mempunyai minat untuk menggunakan sistem ujian online karena puas dengan sistem ujian online yang mudah dipelajari, mudah digunakan, mudah dimengerti, fleksibel dan mudah menjadi mahir dalam mengoperasikan sistem ujian online. Selain itu, beberapa peneliti terdahulu juga telah mengkaji hubungan antara persepsi kemudahan dalam menggunakan dengan minat perilaku (Argawal \& Prasad, 1999; Davies et al., 1996; Venkatesh \& David, 2000; Venkatesh \& Morris, 2000). Oleh sebab itu, hipotesis yang dirumuskan adalah.

H5: Persepsi kemudahan dalam menggunakan (perceived ease of use) berpengaruh signifikan terhadap minat untuk menggunakan (behavioral intention to use).

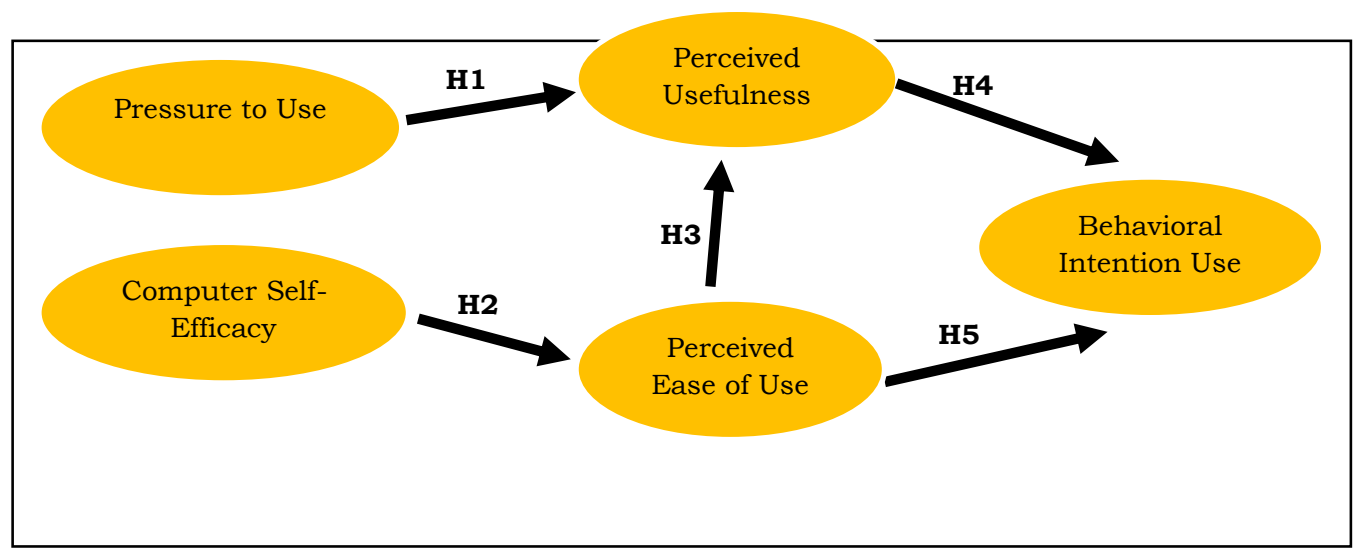




\section{METODE PENELITIAN}

Obyek dari penelitian ini diantaranya adalah persepsi kegunaan, persepsi kemudahan dalam penggunaan, perilaku menggunakan teknologi, tekanan untuk menggunakan dan kemampuan menggunakan komputer. Sedangkan, subyek penelitian adalah mahasiswa yang telah memprogram mata kuliah komputer akuntansi. Penelitian ini berfokus pada bagaimana proses penerimaan dan penggunaan software accurate yang mana digunakan selama proses perkuliahan pada mata kuliah komputer akuntansi selama ini.

Data primer pada penelitian ini diperoleh dari kuesioner yang disebarkan kepada mahasiswa

\section{Tabel 1}

Jumlah Mahasiswa Terdaftar pada Semester Ganjil 2017/2018 pada Program Studi S1 Akuntansi

\begin{tabular}{|l|c|c|}
\hline No & Tahun/Angkatan & Jumlah (Orang) \\
\hline 1 & 2014 & 216 \\
\hline 2 & 2015 & 242 \\
\hline 3 & 2016 & 272 \\
\hline \multicolumn{2}{|c|}{ Total } & 730 \\
\hline
\end{tabular}

Sumber: UPT Fakultas Ekonomi, 2018

Adapun, total sampel yang diperoleh dengan menghitung menggunakan rumus Slovin adalah 88. Berdasarkan jumlah sampel tersebut akan ditentukan

Program Studi S1 Jurusan
Akuntansi Fakultas Ekonomi Universitas Tadulako. Sementara, data sekunder pada penelitian ini diperoleh dari UPT Komputer Fakultas Ekonomi yang meliputi data jumlah mahasiswa Jurusan Akuntansi. Selain itu, telaah literatur juga dilakukan untuk menambah informasi terkait.

Populasi penelitian ini adalah mahasiswa program studi S1 jurusan akuntansi angkatan 2014, 2015, dan 2016. Hal ini dikarenakan mahasiswa angkatan tersebut telah memprogram mata kuliah komputer akuntansi. Jumlah mahasiswa program studi S1 jurusa akuntansi angkatan 2014, 2015, dan 2016 adalah 730 mahasiswa yang mana terinci sebagai berikut.

\section{Tabel 2}

Proporsi Jumlah Sampel pada Tiap Angkatan

\begin{tabular}{|c|c|c|c|c|}
\hline No & Angkatan & Jumlah Populasi & Proporsi sampel & Jumlah sampel \\
\hline 1. & 2014 & 216 & $\begin{array}{c}\frac{216}{730} \times 100 \%=30 \% \\
30 \% \times 88=27\end{array}$ & 27 \\
\hline 2. & 2015 & 242 & $\begin{array}{c}\frac{242}{730} \times 100 \%=33 \% \\
33 \% \times 88=29\end{array}$ & 29 \\
\hline 3. & 2016 & 272 & $\begin{array}{c}730 \\
730\end{array} 100 \%=37 \%$ & 32 \\
\hline
\end{tabular}


Metode analisis data yang digunakan pada penelitian ini adalah partial least square (PLS) dengan persamaan structural equation modeling (SEM).

\section{HASIL DAN PEMBAHASAN}

Menurut Hartono (2008) dalam Jogiyanto \& Abdillah (2009), suatu hipotesis dinyatakan diterima apabila $t$-statistic lebih tinggi daripada nilai t-table dan sebaliknya.

Tabel di atas menunjukkan bahwa tekanan untuk menggunakan software Accurate berpengaruh positif signifikan terhadap persepsi kegunaan dari software tersebut. Hal ini tampak dari nilai $t$-statistic 3,052 yang lebih besar dari t-table 1,96, sehingga $\mathrm{H} 1$ diterima.

Paksaan dalam menggunakan suatu sistem akan mempengaruhi bagaimana persepsi seseorang dalam menanggapi kegunaan dari suatu sistem (Abdel, 2008). Software accurate yang merupakan sotware pada mata kuliah wajib komputer akuntansi bagi setiap mahasiswa program studi $\mathrm{S} 1$ jurusan akuntansi dapat diterima dengan baik dikarenakan pada awalnya setiap mahasiswa diwajibkan mata kuliah komputer akuntansi. Paksaan secara tidak langsung bagi setiap mahasiswa komputer akuntansi tersebut dapat diterima dengan baik oleh mahasiswa. Sistem tersebut sesuai dengan harapan mahasiswa dengan kewajiban yang harus dipenuhi yang pada akhirnya mahasiswa dapat menerima software Accurate dengan baik.

Harapan yang sesuai dengan hasil penggunaan sebelumnya pada software Accurate yang dari hasil penelitian didapatkan bahwa mahasiswa percaya kedepannya software tersebut dapat dipergunakan secara efisien. Kehadiran software tersebut juga diyakini akan mempersiapkan mahasiswa dalam menyambut era pembutan laporan keuangan dengan menggunakan sistem teknologi yang lebih modern. Melalui software Accurate, mahasiswa juga diwajibkan mengerti bahasa Inggris yang digunakan oleh sistem, karena setiap perintah yang digunakan dalam software Accurate menggunakan bahasa Inggris. Dalam hal ini harapan dan kewajiban penggunaan terpenuhi dengan baik sehingga ketika hal tersebut terpenuhi maka tekanan pada penggunaan akan mempengaruhi kegunaan software Accurate.

Tabel 3

Hasil Pengujian Hipotesis

\begin{tabular}{|c|c|c|c|c|c|}
\hline & $\begin{array}{c}\text { Original } \\
\text { Sample } \\
(\mathrm{O})\end{array}$ & $\begin{array}{c}\text { Sample } \\
\text { Mean } \\
(\mathrm{M})\end{array}$ & $\begin{array}{c}\text { Standard } \\
\text { Deviation } \\
\text { (STDEV) }\end{array}$ & $\begin{array}{c}\text { t Statistics } \\
(\mid \text { O/STDEV|) }\end{array}$ & $\begin{array}{c}\mathrm{p} \\
\text { Values }\end{array}$ \\
\hline $\begin{array}{c}\text { Computer Self } \\
\text { Efficacy -> Perceived } \\
\text { Ease of Use }\end{array}$ & 0,308 & 0,329 & 0,074 & 4,149 & 0 \\
\hline $\begin{array}{c}\text { Perceived Ease of Use } \\
\text {-> Behavioral } \\
\text { Intention to Use }\end{array}$ & 0,424 & 0,435 & 0,082 & 5,158 & 0 \\
\hline $\begin{array}{c}\text { Perceived Ease of Use } \\
\text {-> Perceived } \\
\text { Usefulness }\end{array}$ & 0,411 & 0,411 & 0,086 & 4,793 & 0,015 \\
\hline $\begin{array}{c}\text { Perceived Usefulness } \\
\text {-> Behavioral }\end{array}$ & 0,229 & 0,229 & 0,094 & 2,436 & 0,002 \\
\hline $\begin{array}{c}\text { Intention to Use } \\
\text { Pressure to Use -> }\end{array}$ & 0,287 & 0,297 & 0,094 & 3,052 & 0 \\
\hline
\end{tabular}

Sumber: Output PLS, 2018 
Hasil penelitian ini sesuai dengan temuan penelitian terdahulu yang dilakukan oleh Abdel (2008) yang juga menunjukkan terdapat hubungan tekanan untuk menggunakan dan persepsi kegunaan. Hal ini terjadi karena mahasiswa telah ditekankan akan pentingnya mempelajari dan menggunakan software Accurate di masa yang akan datang serta manfaatnya bagi mahasiswa ketika diharuskan untuk memprogram mata kuliah komputer akuntansi, menghasilkan laporan keuangan, dan menghadiri setiap pertemuan dengan ketentuan yang telah diatur. Sehingga tekanan yang baik akan menghasilkan kegunaan yang baik dalam mempelajari software Accurate.

Tabel 3 juga menunjukkan bahwa kemampuan menggunakan software Accurate berpengaruh positif dan signifikan terhadap persepsi kemudahan dalam menggunakan software Accurate. Nilai $t$-statistic 4,149 lebih besar dari nilai t-table 1,96 sehingga $\mathrm{H} 2$ pada penelitian ini diterima. Hasil tersebut menunjukkan bahwa kemampuan seseorang dalam menggunakan komputer mempengaruhi kemudahannya dalam mempelajari software Accurate.

Persepsi kemudahan dalam menggunakan sebuah sistem informasi merupakan suatu keadaan di mana individu meyakini bahwa tidak diperlukan banyak upaya untuk menggunakan sistem informasi tersebut (Davis, 1989). Apabila individu memiliki kemampuan dalam menggunakan komputer, maka individu tersebut akan mudah menggunakan sistem informasi baru.

Dalam penggunaan software Accurate di kalangan mahasiswa didapatkan bahwa peranan dosen dalam membantu mahasiswa untuk mempelajari software Accurate memiliki mean tertinggi. Hal ini menunjukan bahwa peranan dosen sebagai seorang yang terlebih dahulu telah memahami secara utuh mengenai cara kerja dan pengoperasian sistem tersebut,

selanjutnya pengetahuan dan
pengalaman tersebut dibagikan kepada mahasiswa yang diajar. Melalui hal tersebut juga berarti bahwa mahasiswa akan mengalami kesulitan jika mereka harus mempelajari software Accurate tanpa bantuan dosen yang mendampingi. Pernyataan serupa terdapat dalam kuesioner dan dalam hasilnya didapatkan bahwa pernyataan tersebut mendapatkan mean terendah. Oleh karenanya dapat dikatakan bahwa bimbingan dari dosen yang mengajar sangat penting agar mahasiswa dapat memahami pemakaian software Accurate dengan baik.

Hasil penelitian Hwang \& Yi (2002) menunjukkan bahwa semakin baik kemampuan mahasiswa dalam mengoperasikan komputer maka semakin mudah untuk mengoperasikan sistem informasi lainnya. Kemampuan mengoperasikan komputer akan mempermudah mahasiswa dalam mengoperasikan software Accurate.

Tabel 3 juga menunjukkan bahwa persepsi kemudahan dalam menggunakan software Accurate berpengaruh positif dan signifikan terhadap persepsi kegunaan software Accurate. H3 diterima karena nilai t-statistic 4,793 lebih besar dari nilai t-table 1,96. Hasil tersebut bermakan bahwa persepsi kemudahan dalam menggunakan software Accurate mempengaruhi persepsi mahasiswa terhadap kegunaan software Accurate.

Kemudahan penggunaan suatu sistem akan membentuk persepsi mengenai kegunaan dari sistem tersebut dan sebaliknya (Jogiyanto, 2007). Sementara, mahasiswa cukup mudah memahami menggunakan software Accurate sehingga mereka dapat menyadari kegunaan dari software Accurate.

Jika dibandingkan dengan software serupa dalam membuat laporan keuangan software Accurate merupakan software yang masuk dalam kategori cukup mudah untuk digunakan. Hal tersebut didasarkan pada hasil statistik deskriptif yang menunjukkan bahwa nilai mean tertinggi diperoleh oleh pernyataan 
bahwa software Accurate merupakan software yang mudah untuk digunakan dalam pembuatan laporan keuangan yang berbasis software. Hasil penelitian ini juga menunjukan bahwa software Accurate memiliki keunggulan di mana mahasiswa dapat menggunakannya secara fleksibel serta bahasa sistem yang digunakan cukup mudah untuk dimengerti. Penggunaan yang mudah pada akhirnya membuat mahasiswa dapat merasakan manfaat dari software accurate dalam proses pembuatan laporan keuangan berbasis software.

Hasil ini sesuai dengan hasil penelitian terdahulu yang juga menemukan bahwa persepsi kegunaan dan persepsi kemudahan dalam menggunakan merupakan dua konstruk utama yang dapat digunakan memprediksi penerimaan penggunaan teknologi (Davis, 1989; Straub et al., 1997; Tang \& Chiang, 2009). Hasil tersebut bermakna bahwa kemudahan penggunaan yang dirasakan mempengaruhi kegunaan yang dirasakan. Mahasiswa merasa bahwa software Accurate bermanfaat bagi mereka karena kemudahan dalam penggunaannya yang sesuai dengan harapan mereka terhadap software tersebut.

Penelitian ini juga menemukan bahwa persepsi kegunaan software Accurate berpengaruh positif dan signifikan terhadap perilaku minat mahasiswa untuk menggunakan software Accurate dalam proses perkuliahan untuk membuat laporan keuangan berbasis software. Hasil ini didasarkan pada nilai $t$-statistic 3,052 yang lebih besar dari nilai t-table 1,96 sehingga $\mathrm{H} 4$ diterima. Hasil ini juga menunjukkan bahwa manfaat yang diperoleh dari software Accurate mempengaruhi minat mahasiswa menggunakan software Accurate.

Apabila individu meyakini bahwa suatu sistem informasi berguna, maka individu tersebut akan menggunakan sistem informasi tersebut dan sebaliknya (Jogiyanto, 2007). Hasil penelitian ini menunjukkan bahwa software
Accurate memberikan manfaat bagi mahasiswa dalam proses pembuatan laporan.

Manfaat software Accurate dapat dirasakan oleh mahasiswa sebagaimana yang ditunjukkan oleh hasil kuesioner. Mahasiswa merasa bahwa software Accurate membantu mereka dalam menyusun laporan keuangan daripada menyusunnya secara manual. Selain itu, hasil kuesioner juga menunjukkan bahwa software Accurate lebih efisien dan efektif. Ketika manfaat yang mereka dapatkan dari software Accurate benar-benar bisa dirasakan maka mahasiswa pun dapat menerima software Accurate sebagai alat modern untuk menciptakan laporan keuangan yang lebih baik.

Hasil penelitian ini sejalan dengan temuan penelitian terdahulu, yaitu Khakim (2011) yang mana menemukan bahwa persepsi kegunaan berpengaruh signifikan terhadap perilaku minat untuk menggunakan MYOB. Penelitian tersebut mengungkap bahwa karyawan meyakini MYOB memiliki manfaat dan kegunaan dalam pekerjaannya. Jogiyanto (2007) juga menyatakan bahwa individu akan berminat untuk menggunakan suatu sistem informasi apabila sistem tersebut diyakini dapat memberikan manfaat bagi penggunanya meskipun sulit untuk dioperasikan. Individu akan tertarik menggunakan suatu sistem jika sistem tersebut diyakini dapat membantu dalam pekerjaan individu tersebut. Hal ini juga sejalan dengan hasil penelitian terdahulu yang menemukan bahwa persepsi kegunaan mempengaruhi minat perilaku dalam menggunakan teknologi baru (Davis, 1989; Chau, 1996; Igbaria et al., 1997; Sun, 2003).

Penelitian ini juga mengungkap bahwa persepsi kemudahan dalam menggunakan software Accurate berpengaruh positif dan signifikan terhadap perilaku aktual mahasiswa untuk menggunakan software Accurate dalam proses perkuliahan komputer akuntansi. Hasil ini ditunjukkan pada tabel 3 bahwa tstatistic 5,518 lebih besar dari t- 
table 1,96 yang mana berarti H5 diterima. Hasil tersebut menunjukkan bahwa kemudahan untuk menggunakan software Accurate mempengaruhi perilaku mahasiswa menggunakan software Accurate.

Perilaku menerima suatu sistem saling berkaitan dengan kemudahan sistem tersebut untuk digunakan, sebaliknya jika suatu sistem sulit untuk digunakan maka pengguna tidak akan menggunakannya (Jogiyanto, 2007). Dari hasil kuesioner penelitian didapatkan bahwa software Accurate mudah untuk digunakan sehingga mahasiswa menerimanya dengan baik. Kemudahan dalam menggunakan suatu sistem menentukan apakah sistem tersebut akan diterima dengan baik atau tidak. Berdasarkan hasil kuisioner penelitian ini didapatkan bahwa software Accurate cukup mudah untuk digunakan oleh kalangan mahasiswa, mahasiswa dapat mempelajarinya dan menggunakannya dengan mudah. Hal ini menyebabkan penerimaan software Accurate di kalangan mahasiswa cukup mudah diterima dengan baik. Berdasarkan hasil kuisioner pula, mahasiswa percaya bahwa kedepannya pembuatan laporan keuangan harus menggunakan sistem berbasis komputer, oleh sebab itu kedepannya sistem yang akan dibuat harus mudah untuk digunakan sehingga tetap dapat diterima dengan baik nantinya di kalangan pengguna. Penelitian terdahulu juga menemukan bahwa persepsi kemudahan dalam menggunakan berpengaruh terhadap perilaku untuk menggunakan (Argawal \& Prasad, 1999; Davis et al., 1996; Venkatesh \& Morris, 2000).

\section{E. PENUTUP}

Berdasarkan pembahasan di atas, maka dapat disimpulkan beberapa poin penting sebagai berikut:

1. Mahasiswa dipaksakan untuk menggunakan software Accurate (pressure to use), sehingga hal tersebut membantu mahasiswa dalam memaksimalkan kegunaan software Accurate (perceived usefulness).

2. Kemampuan menggunakan komputer yang dimiliki mahasiswa (computer self efficacy) dapat mempermudah mahasiswa dalam menggunakan software Accurate (perceived ease of use).

3. Software Accurate mudah digunakan (perceived ease of use), sehingga mahasiswa dapat merasakan manfaat/kegunaan software tersebut (perceived usefulness).

4. Software Accurate telah memberikan manfaat bagi mahasiswa (perceived usefulness), sehingga software tersebut dapat diterima di kalangan mahasiswa (behavioral intention to use).

5. Software Accurate mudah untuk digunakan (perceived ease of use), sehingga software tersebut dapat diterima oleh mahasiswa (behavioral intention to use).

Berdasarkan kesimpulan di atas, peneliti merumuskan sejumlah saran kepada peneliti terdahulu, diantaranya:

1. Software Accurate yang digunakan cukup mudah untuk digunakan oleh mahasiswa oleh sebab itu software Accurate haruslah tetap digunakan dalam proses perkuliahan komputer akuntansi.

2. Fasilitas penunjang proses pembelajaran perlu ditingkatkan lagi seperti penambahan jumlah komputer serta beberapa fasilitas yang lain untuk kenyamanan ruang kelas yang digunakan selama proses pembelajaran.

3. Mahasiswa perlu memperbaharui kemampuannya mereka dengan memperdalam kemampuan berbahasa Inggris serta meningkatkan kemampuan menggunakan komputer sehingga di masa yang akan datang mereka benar-benar siap menerima perkembangan teknologi di bidang akuntansi.

Dengan hasil penelitian dan hasil analisis data serta kesimpulan, 
penelitian ini memiliki keterbatasan yaitu karena banyaknya jumlah sampel yang digunakan pada penelitian ini sehingga ketika peneliti menyebarkan kuesioner peniliti tidak dapat mewawancarai responden secara keseluruhan, sehingga hanya beberapa yang peneliti lakukan wawancara secara langsung, sehingga dalam peneiliti membuat kesimpulan, peneliti hanya berdasarkan data yang telah diambil dari hasil kuesioner yang disebarkan kepada responden. Selain itu, pada konstruk eksternal peneliti hanya menambahkan dua konstruk yang belum menggambarkan penelitian ini secara rinci. Pada penelitian mengenai TAM masih ada beberapa konstruk eksternal yang perlu untuk diteliti lebih lagi sehingga dapat menggambarkan hasil penelitian yang lebih baik lagi.

\section{DAFTAR PUSTAKA}

Abdel, Gea Ahmad. 2008. Modeling Student's Intention to Adopt ELearning: A Case from Egypt. Turkish Online Journal of Distance Education, 9 (10).

Agrawal, R. \& Karahana, E. 2000. Times flies when you're having fun: cognitive absorption and beliefs about information technology usage. MIS Quarterly, 24 (200): 665-694.

Chin, W. W. 1998. The Partial Least Squares Approach for Structural Equation Modelling. In Marcoulides, G.A. (Ed). Modern Method for Bussiness Research. Mahwa. NJ. Erlbaum.

Davis, F. D. 1989. Perceived Usefulness, Perceive Ease of Use, and User Acceptance Information Technology Usefulness. MIS Quarterly, 13 (3): 319-340.

Ema, N. S. 2016. Analisis Faktor dalam Menggunakan Layanan Ebill dengan Pendekatan Technology Acceptance Model. Jurnal Ilmu dan Riset Akuntansi, 5 (4).

Ghozali, I. 2013. Aplikasi Analisis Multivariate dengan Program IBM SPSS 21, Edisi 7. Penerbit
Univeristas

Diponegor: Semarang.

Goodhue, D. L. \& Thompson, R. L. 1995. Task-Technology Fit and Individual Performance. MIS Quarterly, 19 (2): 213-236.

https://accurate4tutorial.wordpress .com/about, diakses 8 November 2017.

Imannudin, Akbar \& Dahlia B. G. 2014. Analisis Terhadap Penerimaan Penerapan Sistem Ujian Online oleh Siswa Menggunakan Metode TAM. Media Informatika, 13 (1).

Jannah, G. M., Kartika \& A. Arif. 2015. Analisis Faktor yang Mempengaruhi Penerimaan UNEJ Digital Repository dengan Menggunakan Technology Acceptance Model (TAM). EJournal Ekonomi Bisnis dan Akuntansi, 2 (1): 6-12.

Jogiyanto, Hartono. 2007. Model kesuksesan Sistem Teknologi Informasi. Penerbit Andy: Yogyakarta.

Kudiantoro, Widianto. 2015. Kajian Penggunaan Software Zahir Accounting dengan Pendekatan Technology Acceptance Model. Jurnal Khatulistiwa Informatika, 3 (1).

Saputra, E. S. 2012. Skripsi. Analisis Faktor yang Mempengaruhi Penerimaan dan Penggunaan Software Akuntansi Studi Empiris: Mahasiswa Akuntansi S1 dan D3 Fakultas Ekonomi UNS dengan Pendekatan Technology Acceptance Model.

Tenenhausm et al. 2002. State od art on PLS Path Modelling Through The Available Software. HEC: France.

Venkatesh, V. \& F. D. Davis. 1996. A Model of the Perceived Ease of Use Development and Test. Decision Sciences, 27 (3): 451469.

Venkatesh et al. 2003. User Acceptance of Information Technology: Toward a Unified View. MIS Querterly, 27 (3): 425478. 
Analisis Faktor Penerimaan \& Penggunaan Software Accurate Rekka, Totanan, Sudirman, \& Mayapada)

\begin{tabular}{|c|c|c|}
\hline \multirow{2}{*}{\multicolumn{3}{|c|}{$\begin{array}{c}\text { Widiatmika et } \\
\text { Pengembangan }\end{array}$}} \\
\hline & gan & \\
\hline $\begin{array}{l}\text { Penerimaan } \\
\text { oleh P P }\end{array}$ & $\begin{array}{l}\text { Teknologi } \\
\text { Pelajar }\end{array}$ & \\
\hline Menggunakar & & \\
\hline Technology & $\begin{array}{c}\text { Acceptance } \\
\text { nal Sistem Ir }\end{array}$ & \\
\hline
\end{tabular}

